\title{
INTELLIGENCE QUETIONS (IQ) DALAM PANDANGAN AL-QUR'AN
}

\author{
Kustiana Arisanti*
}

\begin{abstract}
Abstrak: The specialty of humans compared to other craft is mind reason which must be used to think about Allab SWT's verses. Thingking is called intelligence which is understood in a variety of ways by scientist. An understanding og intelligence also gives riise to a variety of discussions about how to trains and process intelligence. In this case the Qur'an has a different understanding of intelligence presented in several verses of the Qur'an with the mention of different words. One of them is the word "Fakkara"
\end{abstract}

Keywords: understanding, intelligence, and the Qur'an

\section{A. Pendahuluan}

Sebagai salah satu mukjizat terbesar yang dimiliki oleh Islam, alQur'an juga menjadi sumber ajaran dan dasar hukum utama dalam Islam. Al-Qur'an menempati posisi sentral dalam pengembangan ilmu-ilmu keislaman, lebih dari itu, al-Qur'an juga sebagai inspirator pemandu geraka-gerakan Islam sepanjang sejarah.Karena itulah pemahaman terhadap al-Qur'an melalui penafsirannya mempunyai peranan yang sangat penting bagi maju mundurnya umat. Pada sisi lain, penafsiran tersebut juga menncerminkan perkembangan corak pikir mereka ${ }^{1}$.

* Dosen Institut IlmuKeislaman Zainul hasan Genggong Kraksaan

1 M.Quraish Shihab, Membumikan al-Qur'an; Fungsi dan Peran Wabyu Dalam Kebidupan Masyarakat, (Bandung: Mizan, 1999), 83 
Pantaslah jika al-Qur'an menempati posisi sentral dalam ilmuilmu keislaman, karena disamping al-Qur'an merupakan sumber ilmu pengetahuan, al-Qur'an juga banyak menginspirasi pembacanya untuk mengembangkan ilmu, menuntun kearah yang benar, memotivasi untuk meraih berbagai ilmu, serta memberikan kedudukan tinggi pencari ilmu. Namun, tidak hanya berhenti pada mengetahui atau berilmu, al-Qur'an juga mendorong pemilik ilmu itu untuk mengamalkan ilmunya.Sehingga dengan pengalaman ilmu tersebut, tujuan kebahagiaan hidup di dunia dan akhirat akan dicapai.

Diantara ayat-ayat tersebut, terdapat ayat yang berisi ajakan, himbauan, bahkan perintah agar manusia mau berdzikir dan berfikir atas segala yang diciptakan Allah.Karena, berdzikir dan berfikir dapat menambah keimanan kita kepada Allah SWT.Munculnya keyakinan dan kesadaran bahwa segala yang ada disekitar kita, bumi, langit, dan semua penghuninya, serta keteraturannya merupakan bukti atas keberadaan, kemahakuasaan serta keagungan Allah. Bahkan Nabi Muhammad SAW mengancam "celakalah mereka yang membacanya, namun tidak mau

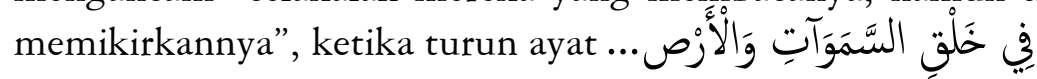

Berdzikir dan berfikir tentang alam semesta, juga akan menjadikan kita manusia peka, yang senantiasa berkeinginan untuk menjadi lebih baik, menjadi rahmah li al-alamin, manusia kreatif, siap mental, spiritual, serta fisik untuk menghadapi perubahan dan fakta-fakta baru. Manusia yang memiliki dan mengembangkan kecerdasan intelegensi.

Namun ternyata, umat Islam saat ini masih kurang memperhatikan ayat-ayat dan sabda Nabi Muhammad SAW tersebut.Masih sedikit diantara kita yang mau berdzikir dan berfikir. Padahal berfikir saja, sebagaimana dikatakan Rasyid Ridha, belum pasti akan menyampaikan kepada keimanan. Demikian juga berdzikir, beriman dengan taklid atau warisan belaka, tanpa didasari berfikir dan mendapatkan bukti keberadaan dan keagunganNya, tentu kurang sempurna.

Untuk itulah dirasa perlu untuk mengkaji ayat-ayat al-Qur'an tentang pengembangan kecerdasan intelegensi, dengan harapan diperoleh pemahaman yang utuh untuk menyeleraskan antara berdzikir dan berfikir dengan menggunakan metode maudhu' $i^{2}$.

2 Penafsiran dengan metode maudhu'i, sebagaimana yang dikemukakan oleh M. Quraish Shihab, dapat menghidangkan pesan al-Qur'an secara lebih efisien, 


\section{B. Pengertian Kecerdasan Berfikir (Intelegensi Quotiont)}

Dalam Kamus Besar Bahasa Indonesia(KBBI), kata cerdas diartikan dengan memiliki kesempurnaan perkembangan akal budi untuk berfikir dan mengerti ${ }^{3}$. Intelegensi berasal dari bahasa latin yaitu Intelegence yang artinya memahami. Adapun pengertian secara istilah terdapat pendapat yang beragam, diantaranya adalah pendapat Edward Thorndike yang mengatakan bahwa intelegensi adalah kemampuan individu untuk memberikan respon yang tepat terhadap stimulan yang diterimanya ${ }^{4}$. Sedangkan Whitherington memberikan ciri-ciri sebagai berikut; pertama, cepat, makin cepat pekerjaan dapat diselesaikan makin cerdas.Kedua, cekatan.Biasanya dikerjakan tangan; mudah dan ringan mengerjakan sesuatu.Ketiga, Tepat, sesuai dengan tuntutan keadaan ${ }^{5}$. Sedangkan intelegensi dalam KBBI dimaknai dengan daya reaksi atau penyesuaian yang cepat dan tepat secara fisik maupun mental terhadap pengalaman baru.Sehingga membuat pengalaman baru dan pengetahuan yang dimiliki siap untuk dipakai apabila dihadapkan pada fakta atau kondisi baru ${ }^{6}$.Dari sini dapat dipahami bahwa kecerdasan intelegensi adalah kemampuan penyesuaian yang sempurna baik fisik, fikiran, maupun mental dalam menghadapi fakta-fakta baru. Sedangkan pengukuran kecerdasan popular dengan istilah Intelligence Quotiont yang disingkat dengan IQ ${ }^{7}$.

mendalam, dan menyeluruh menyangkut tema-tema yang dibicarakannya. Lihat M. Quraish Shihab, Tafsir al-MIsbab; Pesan, Kesan dan Keserasian al-Qur'an, VolI, (Jakarta; Lentera Hati, 2000), vii. Metode maudhu'I ini dilakukan dengan menghimpun ayat-aat al-Qur'an dari berbagai surat dalam al-Qur'an tentang tema tertentu, sambil memperhatikan sebab nuzul, dan munasabah yang kemudian diikuti dengan menjelaskan pengertian ayat-ayat yang mempunyai kaitan dengan tema atau permasalahan yang diajukan penafsir dalam satu kesatuan pembahasan samapi ditemukan jawaban-jawaban menyangkut permasalahan tersebut, Baca selengkapnya dalam Shihab, Membumikan..., 156

3 Tim Redaksi Kamus Besar Bahasa Indonesia, Kamus Besar Bahasa Indonesia (Jakarta; Balai Pustaka,, 2002), 209)

4 Alex Sobur, Psikologi Umum,(Bandung; Pustaka Setia, 2003), 157

5 Ibid. Pendapat tokoh yang lain dapat di baca di Sobur, Psikologi, 155-160

6 Kamus Bahasa Indonesia, 438

7 Pengukuran IQ mulai berlangsung sejak Sir Francis Galton, sepupu Charles Darwin pada tahun 1800-an. Namun mulai berhasil dan diakui pada masa Alfred Binet pada tahun 1900 ketika para pemimpin kota Perancis memintanya memetakan kemungkinan anak muda yang sukses dan gagal, dan dengan IQ di berhasil 


\section{Sejarah dan Kedudukan IQ}

Pada umumnya intelegensi diukur di sekolah serta lembaga pendidikan tinggi dan pengukuran yang dilakukannya cenderung bersifat skolastik, yaitu kemampuan atas materi yang diajarkan di sekolah, yang hasil pengukurannya tersebut dalam satuan IQ.Hal ini menjadikan mereka yang kurang beruntung dalam memperoleh pendidikan sekolah cenderung memiliki skor IQ yang rendah ${ }^{8}$.Padahal ada kemungkinan mereka yang tidak sekolah memiliki kecerdasan lebih tinggi daripada yang bersekolah. Pengukuran IQ ini pun masih dibatasi hanya pada kecerdasan matematis dan linguistik (menulis, membaca dan berhitung), atau dengan memfungsikan otak kiri?.

IQ akhir-akhir ini dianggap kurang mewakili berbagai kecerdasan selain matematik dan logika, utamanya setelah munculnya Frames of Mind karya Howard Gardner pada tahun 1983 dengan tujuh macam kecerdasan secara berurutan, yaitu kecerdasan linguistik, kecerdasan ruang, kecerdasan antar pribadi dan kecerdasan intra pribadi ${ }^{10}$. Berikutnya Gardner menambahkan tiga lagi, yaitu kecerdasan naturalis, kecerdasan spiritual, dan kecerdasan eksistensial ${ }^{11}$.Pada tahun 1995, Daniel Goleman mengatakan bahwa IQ hanya menyumbangkan hanya kira-kira 20 persen dari faktor-faktor yang menentukan kesuksesan dalam hidup dan memberikan berbagai argumentasi kelemahan IQ. Goleman mengatakan bahwa yang 80 persen diisi oleh faktor-faktor lain, kecerdasan emosional merupakan tawaran yang dimunculkan dalam buku larisnya, Emotional Intelligence (EI atau lebih mudahnya EQ Emotional Quotiont) ${ }^{12}$. Dan terakhir muncul Spritual Quotiont (SQ) oleh Danah Zohar dan Ian Mashal sekitar tahun 2000, yang mengatakan bahwa kecerdasan spiritual adalah kecerdasan yang mendapatkan inspirasi, dorongan dan efektifitas yang

membuktikannya. Baca Howard Gardner, Kecerdasan Majemuk, Terj. Alexander Saputra, (Batam; Interaksa, 2003), 19

8 Monty P. Satiadarma dan Fidelis E. Waruwu, Mendidik Kecerdasan, (Yogyakarta: Pustaka Populer Obor, 2003), 2

9 Agus Nggermanto, Quantum Quotiont (Kecerdasan Quantum), Cara Cepat Melejitkan IQ, EQ, dan SQ Secara HArmonis, (Bandung: Nuansa, 2001), 49

${ }^{10}$ Gardner, Kecerdasan, 36-48

${ }^{11}$ Waruwu, Mendidik, 6

${ }^{12}$ Daniel Goleman, Kecerdasan Emosional, Terj. Hernawa (Jakarta: Gramedia Pustaka Utama, 2005), 44-45 
bersumber dari penghayatan ketuhanan kita. ${ }^{13}$ Meskipun demikian IQ telah berjasa selama abad 20, dan tentunya masih perlu dimiliki, meskipun untuk mendapatkan pribadi yang lebih sempurna masih perlu didukung kecerdasan-kecerdasan lain, yaitu Emotional Quotiont dan Spritual Quotiont atau juga Multiple Intelligence.

\section{Pandangan al-Qur'an Tentang Kecerdasan Inteligensi}

Al-Qur'an menyebutkan banyak kata yang dapat dianggap mewakili قرأ، اولو الألباب، نظر، فكر، فقه، : kecerdasan intlektual, diantaranya yaitu مerbagai derivasinya. Dengan bantuan alMu'jam al-Mufakbras li al-Fadz al-Qur'an, penulis mencari data jumlah penyebutan masing-masing kata tersebut dalam al-Qur'an. Sedangkan untuk mengetahui munasabah ayat, penulis menggunakan kitab Nadm ad-Durar fi Tanasub al-Ayat wa al-Suwar dan beberapa kitab lain, untuk menganalisis penulis menggunakan beberapa referensi yang terkait dengan pokok pembahasan.

Hasil pelacakan terhadap beberaapa kata yang mengandung makna ilmu pengetahuan dan beberapa makna yang berdekatan dengannya adalah sebagai berikut ${ }^{14}$ :

\begin{tabular}{|c|c|c|}
\hline NO & $\begin{array}{l}\text { Kata Kunci dengan } \\
\text { Berbagai Derivasinya }\end{array}$ & $\begin{array}{c}\text { Jumlah Penyebutan } \\
\text { dalam al-Qur'an }\end{array}$ \\
\hline 1. & علم & 854 \\
\hline 2 & عقل & 49 \\
\hline 3 & ذز5 & 297 \\
\hline 4. & دبر & 44 \\
\hline 5 & قرأ & 17 \\
\hline 6. & اولو الألباب & 16 \\
\hline 7. & نظر & 128 \\
\hline
\end{tabular}

${ }^{13}$ Nggermanto, Quantum, 113-147

${ }^{14}$ Muhammad Fuad Abd al-Baqi, al-Mu'jam al-Mufakhras li Alfad al-Qur'an, (Http; Dar Matali' al-Shu'b, tth) 


\begin{tabular}{|c|l|c|}
\hline 8. & فك & 18 \\
\hline 9. & فقه & 20 \\
\hline
\end{tabular}

Meskipun demikian, dalam al-Qur'an masih dimungkinkan terdapat banyak lagi kata lain yang dapat mengandung makna sejenis. Banyaknya istilah dan ulangan penyebutan ini juga menunjukkan besarnya perhatian al-Qur'an terhadap ilmu pengetahuan.Namun dengan mempertimbangkan kedekatan kata kunci dengan makna kecerdasan intelegensi, juga untuk memudahkan dalam pembahasan, sehingga dapat lebih terfokus, maka kata kunci yang digunakan disini adalah

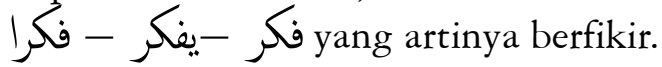

Bagi Rashid Ridha, penyebutan kata فك dengan berbagai derivasinya dalam al-Qur'an, berarti perintah Allah SWT agar kita banyak berfikir, dan berhargaan Allah SWT atas kegiatan berfikir. Ketika kita berfikir, merenungkan ayat-ayat tersebut, bukti-bukti kunniyah dan aqliyah, maka akan banyak muncul pelajaran dan petunjuk berharga bagi kita. Tidak ada petunjuk tanpa adanya kegiatan berfikir, dan manusia adalah makhluk berbahaya, ketika dia tidak mau berfikir ${ }^{15}$.

Sebagaimana tercantum dalam tabel di atas, dengan kata kunci didapatkan 18 ayat dalam al-Qur'an. Ayat-ayat tersebut adalah surat dan ayat sebagai berikut: (QS. 74; 18) makkiyah, (QS. 34; 46) makkiyah, (QS. 2; 219) madaniyah, (QS. 2; 226) madaniyah, (QS. 6;50) makkiyah, (QS. 7; 184) makkiyah, (QS. 30; 8) makkiyah, (QS. 3; 191)madaniyah, (QS. 7; 176) makkiyah, (QS. 10; 24) makkiyah, (QS. 13; 3) madaniyah, (QS. 16; 11) makkiyah, (QS. 16; 44) makkiyah, (QS. 16; 69) makkiyah, (QS. 30; 21) makkiyah, (QS. 39; 42) makkiyah, (QS. 45; 13) makkiyah, (QS. 59; 21) madaniyah. Selanjutnya, diantara ayat-ayat tersebut kami pilih beberapa ayat yang berkaitan langsung dengan tema di atas sebagai sampel yang diharapkan dapat mewakili ayat-ayat lainnya.Untuk mendapatkan pemahaman yang utuh, maka pembahasan atas ayat-ayat tersebut disesuaikan dengan tartib nuzuli yang yang didasarkan pada al-Tafsir alHadits Tartib Suwaar Haitsu Nuzul.

${ }^{15}$ Muhammad Rashid Ridha, Tafsir al-Manaar, Vol. 9, (Beirut: Dar al-Kutub al-Ilmiyah, tth), 339 


\section{E. Pengembangan Kecerdasan Intelegensi Dalam al-Qur'an}

\section{Pengembangan Kecerdasan Intlegensi}

a. Memiliki Kesadaran Sejarah

Presiden Soekarno pernah berkata "Bangsa yang besar adalah bangsa yang menghargai para pahlawannya", karena ketika suatu bangsa menghargai pahlawannya, berarti mereka memiliki kesadaran sejarah. Kesadaran sejarah akan menjadikannya sebagai Negara yang besar. Kesadaran sejarah juga berarti bukan bangsa yang pelupa.

Demikian juga manusia, ketika dia memiliki kesadaran sejarah, maka dia akan dapat memanfaatkan sejarah dan pengalaman orang lain untuk pelajaran dan kebaikan dirinya, dan sebaliknya terbebas dari bencana.

Allah berfirman:

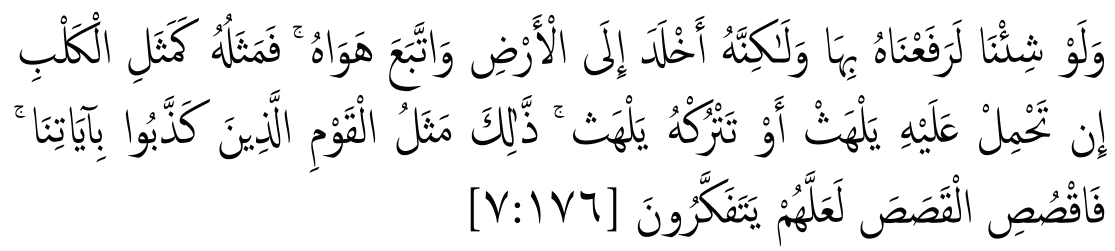

Artinya: "dan kalau Kami menghendaki, sesungguhnya kami tinggikan (derajat) nya dengan ayat-ayat itu, tetapi dia cenderung kepada dunia dan menurunkan hawa nafsunya yang rendah. Maka perumpamaanny a seperti anjing, jika kamu menghalaunya diulurkannya lidahnya dan jika kamu membiarkannya dia mengulurkan lidabnya (juga).Demikian itulah perumpamaan orang-orang yang mendustakan ayat-ayat Kami.Maka ceritakanlah (kepada mereka) kisah-kisah itu agar mereka berfikir". (QS. Al- A'raf; 176)

Ayat ini sebagai penjelas dari ayat sebelumnya yang menceritakan tentang orang ${ }^{16}$ yang menerima ayat-ayat Allah SWT, namun kemudian mereka melepaskan diri dari ayat-ayat itu (demi kepentingan dunia).Dia diikuti syetan sehingga termasuk orang yang

${ }^{16}$ Dalam al-Dur al-Ma'tsur sebagaimana disitir oleh Ridha, disebutkan menurut Abdullah Ibn Mas'ud laki-laki Bani Israil itu bernama Bal'am bin Abr, Menurut Ibn Abbas, laki-laki Bani Isra'il bernama Bal'am bin Ba'ura'. Namun terdapat pula riwayat yang dianggap sebagai asbab al-nuzul dari ayat ini, bahwa laki-laki itu adalah Umayyah bin Abi al-Salat. Dia tinggal di Bahrain.Sebelumnya telah mengakui kebenaran Nabi SAW, namun ketika mengetahui bahwa umat Islam kalah dalam Perang Badar, dia kembali dalam kekufurannya. Lihat Ridha, Tafsir, 341 
tersesat. Padahal seandainya dia mau mengikuti ayat-ayat Allah yang telah mereka pahami, maka Allah akan mengangkat derajatnya. Namun dia malah memilih "kekekalan" dunia dan mempertaruhkan nafsunya serta tidak mau memilih keluhuran, bahkan sebaliknya memilih sesuatu yang hina.

Pendusta ayat-ayat itu, yang sebenarnya telah mendapat ayatayat kauniyah dan aqliyya Allah SWT, seharusnya mengaplikasikan keilmuannya dalam keimanan pada ajaran Allah dan Rasulnya, namun mereka ternyata malah mengingkari.Ini berarti pengetahuannya tidak berguna dan tidak berbeda dengan ketidaktahuannya.Orang seperti ini oleh Allah diserupakan dengan anjing yang selalu menjulurkan lidah, baik ketika dihalau ataudiusir maupun waktu dibiarkan ${ }^{17}$.Dia tidak sadar bahwa perbuatannya sangat buruk, sebagaimana firman Allah dalam ayat sesudahnya sebagai penegasan.

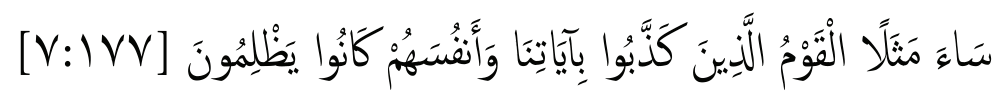

Artinya: "Amat buruklah perumpamaan orang-orang yang mendustakan ayat-ayat Kami dan kepada diri mereka sendirilah mereka berbuat dzalim". (QS. Al-A'raf; 177)

Pelajaran yang dapat kita ambil dari ayat ini adalah: (a) kita mesti memiliki kesadaran dan kecerdasan dalam membaca sejarah, atau atas pengalaman orang lain. Kesadaran dan kecerdasan tersebut, dapat menjadikan sejarah dan pengalaman orang lain sebagai pelajaran yang sangat berharga bagi kita. (b) Allah tidak hanya menyuruh kita cerdas dalam membaca sejarah, namun Allah juga memberikan contoh kasus yang dapat menjadi bahan analisis kita. Pemberian contoh ini, menurut Ridha, sangat penting daripada hanya argumentasi saja dan ini ditegaskan Allah dalam ayat berikutnya (QS. Al-A'raf; 177).

b. Menyadari bahwa Kehidupan Selalu Mengalami Perubahan

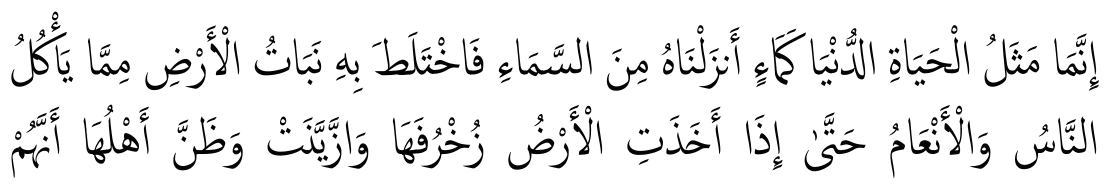

${ }^{17}$ Ridha, Tafsir, 336- 337 


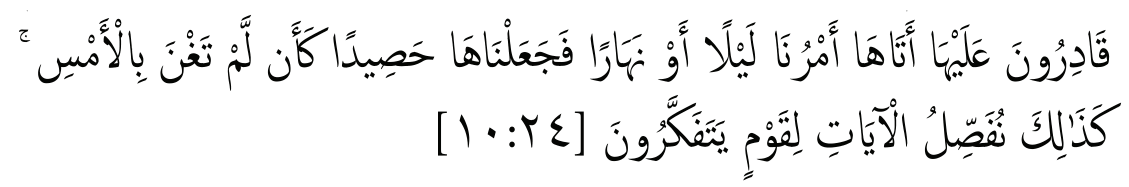

Artinya: "sesungguhnya perumpamaan kehidupan duniawi itu adalah seperti air (hujan) yang kami turunkan dan langit, lalu tumbuhlah dengan suburnya. Karena air itu tanam- tanaman bumi, diantaranya ada yang dimakan manusia dan binatang ternak. Hingga apabila bumi itu telah sempurna keindahannya, dan memakai (pula) perhiasannya, dan pemilik-pemiliknya mengira bahwa mereka pasti menguasainya, tiba-tiba datanglah kepadanya azab kami di waktu malam atau siang, lalu kami jadikan (tanam-tanamannya) laksana tanam-tanaman yang sudah disabit, seakan-akan belum pernah tumbuh kemarin. Demikianlah kami menjelaskan tanda-tanda kekuasaan (kami) kepada orang-orang berfikir”. (QS. Yunus; 24)

Dunia terus berputar, kehidupan juga demikian. Karena itu ada yang mengatakan "Tiada yang kekal kecuali perubahan itu sendiri", dan tentunya Allah SWT. Ibnu Katsir mengatakan, bahwa kehidupan dunia bagaikan keindahan hidup, namun sayangnya sangat mudah hilang lenyap ${ }^{18}$.Demikian hukum kehidupan dunia.Karena itu, maka manusia harus selalu siap menghadapi perubahan.Harapannya tentu perubahan yang mengarah pada kebaikan dan ke arah positif. Denngan menyadari ini, seorang yang cerdas secara intelegensi akan selalu siap menghadapi perubahan. Dia tidak akan mengalami rasa cemas atau keberlanjutan, karena menyadari hokum Allah SWT.

\section{c. Selalu Siap Menghadapi Kematian}

Banyak orang takut pada kematian, orang yang memiliki kecerdasan intelegensi siap menghadapi kematian. Dia memiliki kesadaran bahwa kematian adalah suatu yang pasti, yang tak mungkin dielakkan.Dia juga memiliki keyakinan bahwa Allah lah yang memiliki kekuasaan untuk menghidupkan sekaligus mematikan makhlukNya kapan saja.Karena itu kematian tidak perlu dicemaskan apalagi ditakuti. Sebaliknya, dengan memiliki kesadaran ini, dia akan menganggap setiap detik kehidupan yang dialaminya sebagai kesempatan, untuk

${ }^{18}$ Ibnu Katsir, CD al- Maktabah al-Shamilah, Tafsir Ibnu Katsir, Vol. 2543 
beramal dalam rangka menyiapkan diri pada kematian.

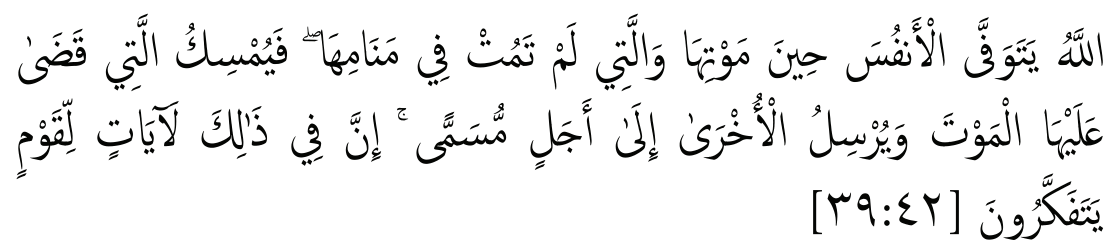

Artinya: "Allab memegang jiwa (orang) ketika matinya dan (memegang) jiwa (orang) yang belum mati di waktu tidurnya; maka dia tabanlah jiwa (orang) yang telah dia tetapkan kematianny a dan dia melepaskan jiwa yang lain sampai waktu yang ditetapkan. Sesunggubnya pada yang demikian itu terdapat tanda-tanda kekuasaan Allah bagi kaum yang berfikir". (QS. Az-Zumar; 42)

Setiap waktu ada kemungkinan kematian menjemput.Ketika manusia tidur, ruh mereka diambil oleh Allah dikumpulkan dengan ruh-ruh manusia yang telah mati.Ketika Allah berkehendak mematikannya, maka ruh tersebut ditahan, ketika menghendaki kehidupan ruh-ruh itu ditahan-Nya ${ }^{19}$.Namun ketika ajal telah datang, maka tidak dapat dimajukan atau pula ditangguhkan. Allah berfirman:

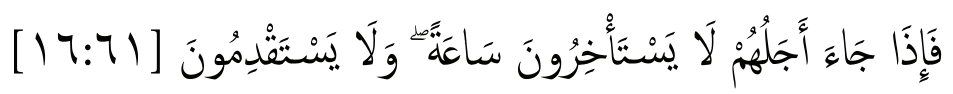

Artinya: "Maka apabila telab datang waktunya mereka tidak dapat mengundurkannya barang sesaatpun dan tidak dapat (pula) memajukannya". (QS. An-Nahl;61)

d. Menyelaraskan Antara Berzikir dan Berfikir

Sebagaimana disebutkan dimuka, bahwa al-Qur'an memberikan banyak perhatian pada ilmu pengetahuan, yaitu ilmu pengetahuan yang tetap berdasar dan bertujuan untuk ibadah pada Allah.Hal ini dapat dicapai dengan menyatukan antara berzikir dan berfikir.

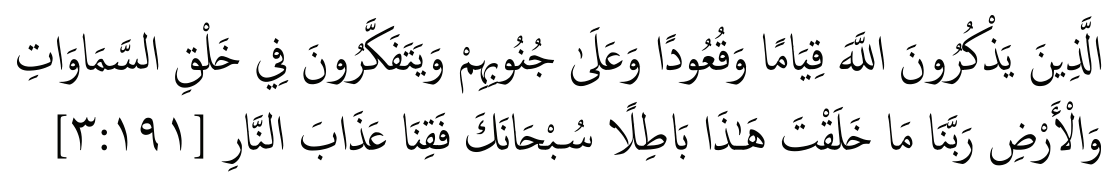

Artinya: "(yaitu) orang-orang yang mengingat Allah sambil berdiri atau

${ }^{19} \mathrm{Al}$-Tabari, Tafsir al-Tabari, CD al-Maktabah al-Shamilah, Tafsir al-Thabari, Vol. 11, 9 
duduk atau dalam keadaan berbaring dan mereka memikirkan tentang penciptaan langit dan bumi (seraya berkata): "Ya Tuhan kami, tiadalah Engkau menciptakan ini dengan sia-sia, Maha Suci Engkau, Maka peliharalah kami dari siksa neraka". (QS. Ali- Imron; 191)

Disebutkan bahwa sebab turunnya ayat ini adalah suatu malam tatkala Nabi SAW bersama Aisyah, Nabi bertanya kepadanya "apakah kau mengizinkanku beribadah kepada Allah?”, Aisyah mempersilahkan NAbi untuk shalat. Nabi menangis dalam shalat, sampai-sampai kata Aisyah "bumi basah oleh air matanya". Selanjutnya Bilal adzan shalat subuh. Mellihat Nabi menangis, Bilal bertanya "Mengapa engkau menangis, padahal Allah telah mengampuni semua dosamu, baik yang telah lewat maupun yang akan datang? Kata Nabi SAW "Apakah aku tidak layak untuk banyak bersyukur". Nabi SAW melanjutkan "Bagaimana aku tidak menangis. Semalam telah diturunkan ayat: Celakalah mereka yang membacanya namun tidak mau memikirkannya"20.

Kalau dalam ayat sebelumnya setelah Allah SWT menyatakan sebagai penguasa atas segala yang ada di bumi dan di langit, penguasa segala ketetapan atau takdir. Maka disini Allah SWT memberikan cara untuk memperoleh keyakinan itu, yaitu dengan berdzikir dan berfikir. Karena dengan selalu berdzikir dan berfikir atas segala ciptaanNya, baik di bumi maupun di langit, kepercayaan, keyakinan atas ayat sebelumnya akan dapat diperoleh. Inilah tujuan terpenting dari surat ini, yaitu mengajak kepada keimanan dan kepasrahan sehingga akhirnya diperolehnya cahaya hati ${ }^{21}$, keyakinan keesaan, serta keagungan Allah ${ }^{22}$.

Allah SWT menjuluki orang yang berdzikir dan berfikir dengan sebutan Ulul Albab.Dan berikutnya Allah SWT memberikan tanda bagi Ulul Albab yaitu mereka yang senantiasa melakukan zikir tanpa

${ }^{20}$ Muhammad Bin Umar al-Zamakhsary, al-Kasyaf 'an Haqaiq Ghawamid alTanzil wa 'Uyun al-aqawil fi Wujub al-Tanzil, Vol. I (Beirut: Dar al-Kutub al-'Arabi, tth), 452

${ }^{21}$ Burhan al-Din Abi al-Hasan Ibrahim Ibn Umar al-Biqa'I, Nazm al-Durar fi Tanasub al-Ayat wa al-Suwar, Vol. II (Beirut: Dar al-Kutub al-'Ilmiyah, tth), 196

${ }^{22}$ Wahbah Zuhaily, al-Tafsir al-Munir fi al-'Aqidah wa al-Shari'ah wa al-Manhaj, Vol. 3 (Beirut; Dar al-Fikr al-Mu'asir, tth), 205-206 
melupakan berfikir dalam segaa kondisi, baik ketika berdiri, duduk, juga tatkala istirahat ${ }^{23}$.

Sebaliknya Shaitan selalu menghalangi manusia untuk berfikir, karena akan dapat meyingkap berbagai keajaiban, dan akhirnya memunculkan keimanan pada Allah SWT. Nabi SAW dalam peristiwa Isra' Mi'raj bersabda riwayat Abu Hurairah:

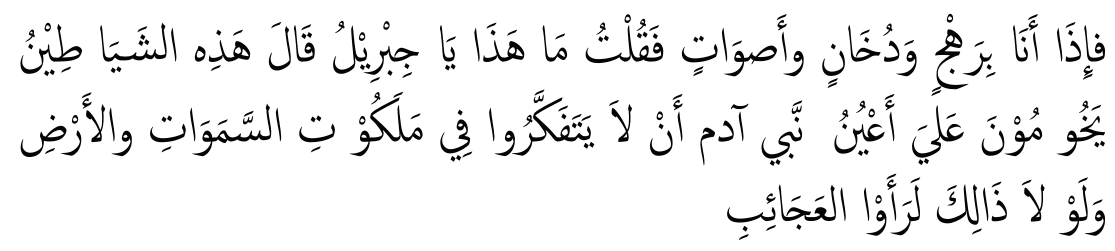

Artinya: "...ketika itu aku menemui debu, asap, dan suara. Kemudian aku bertanya pada Jibril, "Apakah ini?". "Ini adalah Shaitan yang menutupi mata anak Adam agar mereka tidak berfikir tentang kerajaan langit dan bumi.Karena sseandainya mereka berfikir, maka mereka pasti akan melihat banyak keajaiban"24.

Namun demikian Nabi SAW membatasi kita agar berfikir tentang makhluk ciptaan Allah SWT saja, bukan berfikir tentang Allah, karena berfikir tentang Allah SWT tidak akan dapat menyampaikan kita pada hakikatNya. Malah dikhawatirkan dapat menjerumuskan kita pada kekufuran. Sebagaimana hadits riwayat al- Ashbani dari Ibnu Abbas:

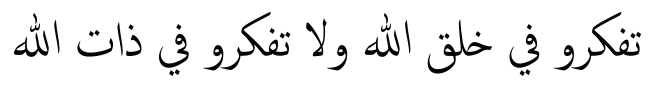

Artinya: "Berfikirlah atas segala hal, tapi jangan berfikir tentang Dzat Allab"

Melihat tingginya nilai berfikir, yang akan dapat menyingkap berbagai kebenaran, menambah keimanan maka Hasan al-Basri mengatakan bahwa berfikir satu saat lebih utama daripada shalat sunnah semalaman ${ }^{25}$ :

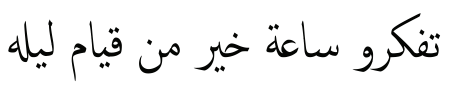

${ }^{23}$ Al-Biqa'I, Nazm, 197. Lihat juga Zuhaily, al-Tafsir, 207

${ }^{24}$ Ahmad Bin Hambal, dalam CD Mausu'ab al-Hadits al-Sharif. Hadits nomor 8286, dengan nilai marfu', muttashil lebih dari satu sanad

${ }^{25}$ Al-Zuhaily, al-Tafsir, 207 


\section{Kesadaran Tugas Intelegensi}

Sebagai orang yang berilmu dan memiliki berbagai kelebihan sebagaimana disebutkan di atas, seorang cerdas intelegensi dituntut untuk mengamalkan dan memanfaatkan kecerdasannya, dengan tujuan mengabdi pada Allah SWT. Diantara bentuk pengabdiannya adalah sebagaimana difirmankan oleh Allah SWT:

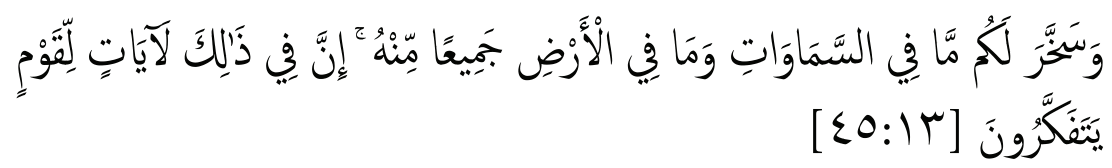

Artinya: "Dan Dia telab menudukkan untukmu apa yang di langit dan apa yang di bumi semuanya, (sebagai rahmat) daripadaNya. Sesunggubnya pada yang demikian itu benar-benar terdapat tanda-tanda (kekuasaan Allah SWT) bagi kaum yang berfikir". (QS. al-Jastiyah; 13)

Karena Allah SWT telah menundukkan langit dan bumi untuk kepentingan umat manusia, maka tugas yang seharusnya dilaksanakan seorang yang memiliki cerdas intelegensi adalah mengeksplorasi alam, dan selalu mengembangkan kecerdasan dan berikutnya mengamalkan hasil pengembangannya.

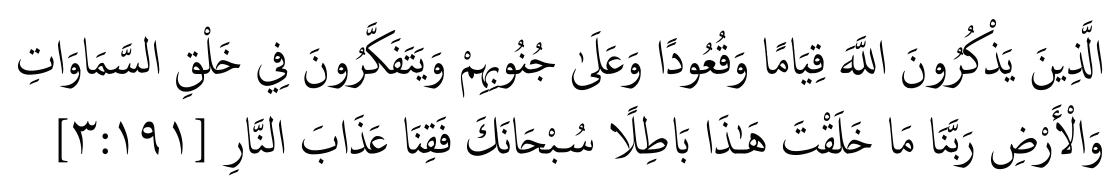

Mereka juga senantiasa berfikir dan berfikir, serta melakukan berbagai penelitian, sehingga ditemukan ilmu-ilmu baru, penemuan-penemuan baru yang dapat menjadikan hidup lebih mudah dan lebih indah.Yang tujuan pokok dari semua itu adalah dapat lebih meningkatkan keyakinan manusia kepada Allah SWT.

\section{Imbalan dari Allah SWT Bagi Yang Mengembangkan Intelegensi}

Allah SWT senantiasa memberikan anugerah bagi mereka yang mau mengikuti, dan mentaati ajaranNya. Demikian juga bagi intelegen yang mau memaksimalkan diri berdzikir dan berfikir, dalam upaya mengeksplorasi ciptaan Allah SWT, agar dapat lebih berguna dan 
bermakna bagi kehidupan umat manusia, sehingga makin kuatlah keimanannya, dan banyaklah yang mengambil manfaat dari ilmunya. Maka baginya janji Allah SWT:

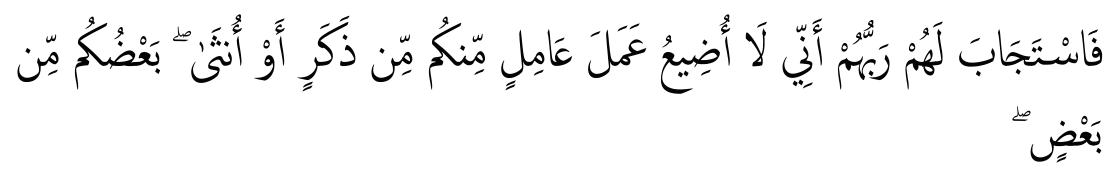

Artinya: "Maka Tuban mereka memperkenankan permobonannya (dengan berfirman): "Sesunggubnya Aku tidak menyia-nyiakan amal oran-orang yang beramal di antara kamu, baik laki-laki atau perempuan, (karena) sebagian kamu adalab turunan dari sebagian yang lain...". (QS. Ali Imron; 195)

Allah SWT mengabulkan do'a mereka, yang diantara isi do'a mereka adalah: diselamatkan dari neraka, diampuninya segala kesalahan, diwafatkan bersama orang-orang yang berbakti, serta mendapatkan segala yang dijanjikan Allah SWT kepada Rasul-rasulNya.

\section{F. Kesimpulan}

Kecerdasan intelegensi adalah kemampuan penyesuaian yang sempurna baik fisik, fikiran, maupun mental dalam menghadapi faktafakta baru yang pengukurannya biasanya dengan menggunakan tes IQ (Intelligence Quotiont).

Setelah IQ ditemukan pada tahun 1900, telah muncul berbagai kecerdasan yang lain, Multiple Intelligence EQ/IQ dan SQ. dan tidak menutup kemungkinan, masih pada masa mendatang muncul penemuan baru tentang intelligence ini.

Pengembangan kecerdasan intelligence dalam al-Qur'an, dengan menggunakan kata kunci فك diperoleh pemahaman sebagai berikut:

1. Prinsip- prinsip pengembangan kecerdasan intelegensi dengan: (a) memiliki kesadaran sejarah; (b) menyadari bahwa kehidupan selalu mengalami perubahan; (c) selalu siap menghadapi kematian; (d) senantiasa menyelaraskan antara berdzikir dan berfikir.

2. Kesadaran tugas intelegensi dilakukan dengan mengamalkan dan memanfaatkan kecerdasannya dengan mengeksplorasi alam memanfaatkannya untuk kepentingan manusia dengan dasar pengabdian pada Allah SWT. 
3. Imbalan yang diterima mereka adalah Allah SWT mengabulkan do'a mereka, yang di antara isi do'a mereka adalah diselamatkan dari neraka, diampuninya segala kesalahan, diwafatkan bersama orangorang yang berbakti, serta mendapatkan segala yang dijanjikan Allah SWT rasul-rasulNya.

Dengan mengembangkan kecerdasan intelegnsi sesuai dengan prinsip-prinsip al-Qur'an di atas, diharapkan muncul manusia yang bukan hanya memiliki kemampuan penyesuaian yang sempurna baik fisik, fikiran, maupun mental dalam menghadapi fakta-fakta baru, namun juga mampu menyelaraskan antara berdzikir dan berfikir untuk kemanusiaan dan menambah keimanan kepada Allah SWT. 


\section{DAFTAR PUSTAKA}

Baqi, Muhammad Fuad Abd al-.al-Mu'jamal-Mufakhras li Alfad al-Qur'an. (Http; Dar Matali' al-Shu'b, tth)

Biqa'I,Burhan al-Din Abi al-Hasan Ibrahim Ibn Umar al-.Nazm al-Durar fi Tanasub al-Ayat wa al-Suwar. Vol. II (Beirut: Dar al-Kutub al'Ilmiyah, tth)

Gardner, Howard. Kecerdasan Majemuk.Terj. Alexander Saputra. (Batam; Interaksa, 2003)

Goleman, Daniel. Kecerdasan Emosional.Terj.Hernawa.(Jakarta: Gramedia Pustaka Utama, 2005)

Hambal, Ahmad Bin .CD Mausu'ah al-Hadits al-Sharif. Hadits nomor 8286

Katsir, Ibnu. CD al- Maktabah al-Shamilah.Tafsir Ibnu Katsir.Vol. 2543

Nggermanto,Agus. Quantum Quotiont (Kecerdasan Quantum), Cara Cepat Melejitkan IQ, EQ, dan SQ Secara Harmonis.(Bandung: Nuansa, 2001)

Ridha, Muhammad Rashid .Tafsir al-Manaar.Vol. 9, (Beirut: Dar al-Kutub al-Ilmiyah, tth),

Shihab, M.Quraish. Membumikan al-Qur'an; Fungsi dan Peran Wabyu Dalam Kehidupan Masyarakat.(Bandung: Mizan, 1999).

Sobur, Alex. Psikologi Umum. (Bandung; Pustaka Setia, 2003)

Satiadarma, Monty P. dan Fidelis E. Waruwu.Mendidik Kecerdasa. (Yogyakarta: Pustaka Populer Obor, 2003)

Tafsir al-MIsbab; Pesan, Kesan dan Keserasian al-Qur'an, VolI, (Jakaarta; Lentera Hati, 2000), vii.

Tim Redaksi Kamus Besar Bahasa Indonesia, Kamus Besar Bahasa Indonesia (Jakarta; Balai Pustaka,, 2002), 209)

Tabari, Al-.Tafsir al-Tabari.CD al-Maktabah al-Shamilah.Tafsir al-Thabari. Vol. 11, 9

Zamakhsary, Muhammad Bin Umar al-.al-Kasyaf'an Haqaiq Ghawamid al-Tanzil wa 'Uyun al-aqawil fi Wujuh al-Tanzil. Vol. I (Beirut: Dar al-Kutub al-'Arabi, tth)

Zuhaily, Wahbah. al-Tafsir al-Munir fi al-'Aqidah wa al-Shari'ab wa alManhaj. Vol. 3 (Beirut; Dar al-Fikr al-Mu'asir, tth) 